Allan M Williams (leading author)

Professor of Tourism and Mobility Studies

University of Surrey

E-mail: allan.williams@surrey.ac.uk

Economic development and mobility, tourism and migration, innovation, productivity and entrepreneurship

Isabel Rodríguez Sánchez

Doctor in Tourism and Research Fellow

Faculty of Arts and Social Sciences

University of Surrey

Guildford GU2 7XH

E-mail: isabel.rodriguez@surrey.ac.uk

Tourism innovation and entrepreneurship; tourism planning; tourism and innovation policies

Teemu Makkonen

Professor

University of Eastern Finland

E-mail: teemu.makkonen@uef.fi

Innovation; regional development; STI cooperation; tourism 


\title{
INNOVATION AND SMART DESTINATIONS: CRITICAL INSIGHTS
}

\author{
Allan M. Williams \\ School of Hospitality and Tourism Management \\ Faculty of Arts and Social Sciences \\ University of Surrey \\ Guildford GU2 7XH \\ E-mail: allan.williams@surrey.ac.uk \\ Isabel Rodriguez Sanchez \\ School of Hospitality and Tourism Management \\ Faculty of Arts and Social Sciences \\ University of Surrey \\ Guildford GU2 7XH \\ E-mail: isabel.rodriguez@surrey.ac.uk \\ Teemu Makkonen \\ University of Eastern Finland \\ Karelian Institute \\ Yliopistokatu 2 \\ P.O. BOX 111 \\ FI-80101 Joensuu \\ teemu.makkonen@uef.fi
}

\begin{abstract}
Smart destinations have become an esteemed concept among researchers and policy makers. Discussion of the concept is optimistic in tone and commonly linked to information rather than knowledge and more to design than innovation, partly explaining relatively limited critical discussion of the (potential) benefits of smart destinations. This article raises selected issues from the innovation, as opposed to the design literature, to offer insightful perspectives on analyzing smart destinations as one manifestation of smart tourism. The discussion emphasises that: 1) smart destinations are driven by uncertainty; 2) knowledge provides deeper insights than information into smart destinations as innovation; 3) entrepreneurs play an important role in facilitating smart destinations; and 4) smart destinations constitute innovation systems.
\end{abstract}

\section{Keywords}

Smart destinations, information, knowledge, uncertainty, design, innovation 


\section{Highlights}

- Smart destinations are driven by uncertainty

- Knowledge provides deeper insights than information into smart destinations

- Entrepreneurs play an important role in facilitating smart destinations

- Smart destinations constitute innovation systems

- Innovation adds a more holistic perspective than design to understand smart destinations 


\title{
INNOVATION AND SMART DESTINATIONS: CRITICAL INSIGHTS
}

\begin{abstract}
Smart destinations have become an esteemed concept among researchers and policy makers. Discussion of the concept is optimistic in tone and commonly linked to information rather than knowledge and more to design than innovation. This partly explains the relatively limited critical discussion of the (potential) benefits of smart destinations. The article raises selected issues from the innovation, as opposed to the design literature, to offer insightful perspectives on analyzing smart destination. The discussion emphasises that: 1) smart destinations are driven by uncertainty; 2) knowledge provides deeper insights than information into smart destinations as innovation; 3) entrepreneurs play an important role in facilitating smart destinations; and 4) smart destinations constitute innovation systems.
\end{abstract}

Keywords

Smart destinations, information, knowledge, uncertainty, design, innovation 


\section{INTRODUCTION}

Researchers, and policy makers, have enthusiastically engaged with the notion of smart tourism so that 'suddenly everything is smart' (Gretzel et al., 2015, p.180). There is a highly optimistic tone to much of the debate (for example, Buhalis \& Amaranggana, 2014; Gretzel, 2016), verging at times on a self-congratulatory assertion of potential while more critical voices are muted. In part this is a consequence of how the 'smart transformation of tourism' agenda is informed by the way in which technological developments are transforming information collection and analysis rather than by broader knowledge and innovation concepts. This failure to engage more fully with innovation theories is surprising because smart tourism is implicitly about innovation; it involves transforming new types of digital data 'into on-site experiences and business value-propositions' (Gretzel et al., 2015), which is essentially the process of innovation. Therefore, this paper seeks critically to examine the notion of smart destinations, as one manifestation of smart tourism, within the essential framework of innovation so that we can better understand and appreciate what 'smart' really means and how innovation can provide a foundation for designing and developing truly smart destinations. Smart destinations are understood to be "places utilising the available [ICT] technological tools and techniques to enable demand and supply to co-create value, pleasure, and experiences for the tourist and wealth, profit, and benefits for the organisations and the destination' (Boes et al. 2015, p. 394); for other, related, definitions see Ozseker (2019) and Trunfio \& Campana (2019).

Much of the debate on smart destinations, and smart tourism more generally, has focused on design rather than innovation. Nevertheless, the overlap between the two conceptual frameworks has been extensively reviewed, with design thinking being seen as 'the iterative process of design, development, and evaluation and the basis of innovation' (Fesenmaier \& Xiang, 2017, p. 8; see also Hernández et al., 2018). Design is an essential part of innovation but only one component of innovation (Hatchuel, 2002). In contrast, innovation comprises the process of creating something new as a whole from ideation to commercialization (Marxt \& Hacklin, 2005), and incorporating key business aspects of delivering a product to market. Innovation is understood as the implementation of any new ideas relating to both products and processes, and these can be new to the firm, to the destination, or to tourism or the economy generally (Hall \& Williams 2020). The innovations may be at the firm level, or can be at the destination level, which usually involves either public or public-private partnerships. There is increasing blurring of the concepts but a failure to heed Hobday et al's. (2011) call for greater mutual interrogation leads to the need to review the contribution of innovation theories to smart tourism generally, and by extension to smart destinations. 
The literature on smart destinations has of course engaged with innovation, but there has tended to be a greater focus on information than on knowledge: for example, Buhalis and Amaranggana (2014, p. 558) state that: 'The flagship of the transformation to Smart Tourism Destinations is destinationwide access to real-time information'. In contrast, in the innovation literature, knowledge and the associated concept of uncertainty rather than information is the point of departure. There is also a strong focus on the innovation process as well as innovation outcomes, which is important because smart destination inventions or designs have to be implemented (that is, via a process) within situated knowledge systems, whereas design is criticized for being de-contextualised (Johansson-Sköldberg et al., 2013).

In addressing this gap, the paper seeks to broaden the conceptualization of smart destinations so that it engages more fully with innovation theories. We focus specifically on the supply side of smart tourism destinations, a special case of smart cities (Gretzel, 2016), rather than the more general concept of smart tourism, that is the production and consumption of smart tourism experiences. We examine tourism products and experiences, and exclude the underlying infrastructures such as cleaning and water system despite their important contribution, so as to focus on the distinctive elements of smart destinations as opposed to smart cities. The remainder of this paper focusses on four key interrelated innovation concepts, which are strongly underpinned by consideration of the nature of knowledge and provide critical insights into the smart destination agenda: uncertainty, knowledge management, the role of entrepreneurship, and the innovation system. It is uncertainty which drives innovation but is also a challenge to the innovation process. At the heart of that process is knowledge management rather than information management, and this is partly about redrawing the border between knowledge and uncertainty. Entrepreneurs play a key role in engaging and shaping the innovation process, especially given the potentially high levels of small firms, and technological start-ups in smart destinations. However, we caution against over-emphasising the role of entrepreneurs, and argue that smart destinations can be understood as innovation systems which shape and are shaped by both entrepreneurial activity but also by institutions.

\section{UNCERTAINTY, COMPETITIVENESS AND COMPETITION}

Starting from knowledge inevitably takes us to uncertainty, the fundamental differentiation between what is known and unknown (Knight, 1921). Design approaches uncertainty as a means of addressing 'wicked problems', that is 'seemingly intractable knotted clusters of interdependent problems or challenges occurring under conditions of uncertainty' (Hobday, 2012). In other words, as a process of reflection for 'resolving ill-defined problems' (Cross, 1990, p. 127). The designer seeks to redefine 
problems by questioning what is known, or thought to be known about a particular issue, opening the way towards a broader space for designing a creative response to this (Hernandez et al., 2018). However, innovation concepts emphasise that uncertainty and risk are central to the entire innovation process. Indeed, in his classic treatise, Knight (1921) concluded that innovation is a response to inherent conditions of uncertainty in economic systems. Firms, and therefore destinations, innovate because uncertainty represents both a threat and an opportunity that can be realized by 'pushing the boundaries of the unknown' (Dvir \& Pasher, 2004, p. 20). By extension, smart destinations can be understood in terms of constituting a response to the pervading uncertainty in an increasingly, highly competitive market for tourism services or experiences. Specifically, that market is being transformed by new uncertainties resulting from potentially transformational reconfigurations of digital technologies, especially mobile technology and the internet of things; moreover, the industry is seeking to build-in controls which will reduce such uncertainties.

The key point about responding to uncertainty via innovation is that the latter is recognised as a, and perhaps the, major source of competitive advantage in any economy (Chell, 2001; O'Connor, 2008; Crossan \& Apaydin, 2010): firms and destinations must not only respond to uncertainties, but they must do so more effectively (competitively) than their competitors. This is why Baumol (2002, p. 55) refers to there being an 'innovation arms race'. It is also why innovation is recognised as being central to what Hall and Williams (2020) term as being 'the high road' to regional tourism development. Smart tourism clearly represents a powerful driver of innovation and competitiveness (Gretzel, 2016; Buhalis \& Amaranggana, 2014) via the provision of potential access to (still largely proprietary) multiple sources of data generated by new configurations of technology (Boes et al., 2015, p. 397). Smart destinations therefore represent the opening of a new front in Baumol's 'innovation arms race', but there is a considerable difference between those strategies which are driven more by information as opposed to total knowledge (Figure 1) as discussed in the following section.

Focusing on competitiveness tends to reinforce the positive narrative about smart destinations as collections of linked innovations, but the notion of 'innovation wars' reminds us that there are also 'casualties'. Whether a smart destination is transformed from drawing board to reality in a greenfield site or, more likely, that it emerges in an existing tourism destination, the process of innovation is, or is likely to be, littered with, often poorly documented, firm, project and innovation failures. Innovation seeks to address uncertainty but 'genuine uncertainty is an unavoidable component of innovation activities' (Edquist \& Johnson, 1997, p. 51). There is uncertainty for the innovator, as well as for its competitors, with respect to how the idea or technology will be translated into a product, and how 
markets will respond to the innovations (O’Connor, 2008). Hence, it is important to note that gener-

ally 'most innovation projects are terminated even before market testing, and among those that reach the markets most do not survive the test' (Edquist \& Johnson, 1997, p. 5). There is no reason to think that this will not apply within smart destinations as in any other destination in a market economy. Individual firms within the destination may reduce their uncertainties, but the very nature of competitiveness means that this may increase competition and uncertainty for their competitors both in the destination and elsewhere. However, the competitiveness of firms in a smart destination may generally be enhanced compared to those in non-smart destinations: that is, we need to consider both interand intra-destination competition. Innovation is both a response to, and shapes ,uncertainty

Furthermore, consideration of the overall impact of a smart destination as a collective set of firm- and destination-level innovations leads to an even more fundamental critique related to whether this constitutes a radical innovation. Radical innovations are important because there are limits to the extent to which incremental innovations can address uncertainty. Transformation of the conditions of (but not the existence of) uncertainty inherently requires radical innovations, but these are associated with 'creative destruction' (Schumpeter, 1942, p. 84): radical innovations result in 'competition which commands a decisive cost or quality advantage and which strikes not at the margins of the profits and the outputs of the existing firms but at their foundations'. This is illustrated by how one of the cornerstones of the smart destination, the internet of things, was considered by the US National Intelligence Council as being in the top six most disruptive civil technologies (Atzori et al., 2010, p. 2787). Moreover, it is still considered to be potentially the most important technological innovation in relation to smart destinations, followed by big data and real time data sets (Ivars-Baidal et al., 2019).

With respect to tourism and new digital technology, Benckendorff, Sheldon \& Fesenmaier (2014) have commented on the disruptive as well as the creative power of Web 2.0 in tourism. Commenting on smart cities, Malanga (2004) states that: 'Smart places are getting smarter while other places are getting less smart because such places act as a magnet for creative people and workers', creating a dichotomy between prosperous (smart) places and "places that don't matter” (Rodríguez-Pose, 2018). However, there is also evidence that potentially radical innovations often have far more limited effects than expected, with many firms (and by extension, destinations) being unable to break out of niche markets (Hjalager, 2014). While the smart destination represents a potential radical innovation, there is no evidence as yet that it has achieved that status in practice - certainly in terms of Schumpeter's creative destruction. It remains a hypothesis. 
There is of course a catching up process for firms or destinations 'that don't matter' (Rodríguez-Pose, 2018) - the smart tourism laggards. Initially, smart destinations were a radical idea but as their diffusion has progressed this innovation has undergone, or will undergo, a process of standardisation. This process has reduced or will reduce the uncertainty for later innovators, in terms of having access to enhanced knowledge about technology and market acceptance/preferences. However, at the same time there are new forms of uncertainty emerging in the form of increasing competition, especially from first movers. That competition is intensified by the role that consultancy firms play in the design and creation of smart destinations: they bring global experience to local destination challenges, but this also involves a high degree of imitative innovation in the form of one-size-fits-all designs (Glasmeier \& Nebiolo, 2016). As always, any innovation - smart or non-smart - is likely to unleash a wave of other innovations, whether imitative or reactive.

In short, the pathways to competitiveness necessarily are shaped by, and shape, uncertainty for smart tourism destinations. Those pathways can be understood as being littered not only with shining beacons of success as projected in the smart tourism literature, but also with failed innovations, firms and, in extremis, the potential risk of stagnation or relative decline of those destinations which failed to engage effectively with the new paradigm. Smart destinations are created to manage uncertainty and risks in destinations but paradoxically generate new risks and uncertainties within them and for competitor destinations. As such, uncertainty is an unavoidable component of smart destinations.

\section{KNOWLEDGE MANAGEMENT AND MISMANAGEMENT}

The most common response to uncertainty in smart destinations, as in any innovation or set of innovations, is to seek to increase knowledge so as to shift the boundary between known risks and unknown risks or uncertainty (Williams \& Baláž, 2015). The associated process of knowledge management is constituted of different elements - knowledge creation, transfer, and storage (Argote \& Miron-Spektor, 2011) - all of which apply to smart firms, in common with all firms, within tourism destinations. The design literature is particularly strong on knowledge creation (Marxt \& Hacklin, 2005), but here we focus on knowledge transfer which has been a major strand in the innovation literature and is highly implicit in the conceptualization of smart tourism destinations, albeit mostly articulated in terms of the narrower concept of information transfer. 
There is broad consensus around Argote and Ingram's (2000, p. 150, emphasis added) argument that

the ' ... knowledge embedded in the interactions of people, tools and tasks provides a basis for competitive advantage in firms'. A selective consideration of the vast literature on knowledge transfer also provides a means to interrogate some of the, often implicit, knowledge assumptions of smart destinations. Much of the earlier literature on the smart city was 'techno-myopic' (Gretzel et al., 2015), reminiscent of the earlier overly-narrow focus on technology in manufacturing innovation research (Hall \& Williams, 2020). Such techno-myopia reflects how the term smart has been transferred from the technological to the social sciences, with the greater complexity that the latter involves. The outcome has been a tendency to emphasise the unquestioned value of harvesting and collating data (tourists' emotive and reasoned responses) via digital means, rather than draw on the broader concept of knowledge. This chimes with Fesenmaier and Xiang's (2017, p. 10)'s view that we live in an increasingly 'data-driven sensor society', but data or information only have value when transformed into knowledge, that is when they are interpreted (see Figure 1 for the relationship to uncertainty). This critique is partly recognised in the later writing on the smart concept: for example, Nam and Pardo (2011) emphasise the smart city has technological, human and institutional dimensions. However, the innovation literature brings a broader understanding of the role of knowledge management.

\section{FIGURE 1 ABOUT HERE}

As a starting point, the difference between codified and tacit knowledge (Polanyi, 1958) is well established in tourism innovation research (Hall \& Williams, 2020). Codified knowledge is that which can be made explicit, and therefore can be transmitted in formal, impersonal and systematic ways, including the digital formats which are central to smart destinations, while tacit knowledge is essentially personal knowledge. The smart destination particularly seeks to innovate radically in the collation, distribution and analysis of codified knowledge, and - where possible - capture the tacit knowledge of individuals and transform it into codified form: for example, via tourists' digital diaries or using sensors to measure affect (reflecting emotional knowledge).

However, there are limits to the translation of tacit into codified knowledge (Nonaka \& Takeuchi 1995). Polanyi (1958; 1966) emphasised that tacit knowledge is difficult, and in some ways impossible, to express in words or in any other explicit form: it is 'ineffable' (Grant, 2007, p. 175-6). This is 
further illustrated by Blackler's (2002) identification of four main types of tacit knowledge: em-

brained knowledge dependent on conceptual skills and cognitive abilities; embodied knowledge results from experiences of physical presence, including practical skills; encultured knowledge formed via socialization and acculturation; and embedded knowledge which is embedded in contextual factors and includes an understanding of specific institutions. Many aspects of these types of knowledge, especially the embodied, cannot be transformed into codified knowledge, and relies instead on person to person interaction, including observation, either in digital space or (sometimes only in) physical space, to transfer some types of tacit knowledge to others. However, the contextualized place-specific knowledge, inherent to destinations, can often be "sticky", i.e. geographically relatively immobile (Asheim \& Isaksen, 2002), and difficult to transform but that is why it is key to the importance of total knowledge (including the tacit component) compared to information (Figure 1).

The smart destination, in common with all economic organizational forms, faces major challenges in capturing tacit knowledge, some of which is 'ineffable' (Grant, 2007, p. 175-6). Both the destinationlevel organisation and individual firms not only need to be able to harvest various forms of codified knowledge from fixed and mobile sources, but also have capacity to combine it effectively with their individual and collective tacit knowledge of the market, of business practices, etc. As Asheim and Coenen (2006, p. 164) argue, the value of transferred codified knowledge '... relies on tacit knowledge embedded in people and organizations to be understood and applied'. This leads Maskell and Malmberg (1999) famously to argue that because of the 'ubiquification' of codified knowledge - a process amplified in the digital economy - tacit knowledge has become highly significant to competitiveness.

Given the importance of both codified and tacit knowledge in addressing uncertainty, considerable attention has been given to the concept of 'absorptive capacity'. The originators of this term, Cohen and Levinthal (1990), understand it to mean the ability of the firm to recognize, assimilate, and commercialize new knowledge. Central to this is the integration of new and existing knowledge, and implicitly of tacit and codified knowledge. Cohen's original concept is refined by Zahra and George (2002) who distinguish between the potential capacity of the organisation (identification and assimilation of knowledge) and the realised potential (transformation and exploitation of knowledge). The concept can also be scaled up to regions which have differential absorption capacity (Oughton et al., 2002). Turning to tourism generally, Thomas and Wood $(2014 ; 2015)$ found broad, but not entirely conclusive, empirical evidence that this fourfold typology applies to different tourism sectors. The concept has particular application to smartness which can be understood as both a process of increas- 
ing absorptive capacity, and as an outcome of the enhancement of absorptive capacity. This is re-

flected in Gretzel et al's (2015, p. 181) definition of smart tourism, and by extension to smart destinations, as: 'tourism supported by integrated efforts at a destination to collect and aggregate/harness data derived from physical infrastructure, social connections, government/organizational sources and human bodies/minds in combination with the use of advanced technologies to transform that data into on-site experiences and business value-propositions'.

The identification and assimilation stages of absorption capacity have the clearest parallels with the emphasis on collection, aggregation and integration in Gretzel et al's (2015) definition. However, it is important to note that Autio et al. (2000) contend that the absorption of new knowledge is conditioned by the requirement that participants need to unlearn some aspects of their old or existing knowledge. This can be highly challenging where tacit knowledge is a particularly important component of existing knowledge in the firm, especially when rooted in cultured and embedded knowledge jointly developed by groups of workers within the organization. Some of this knowledge may be, in Polanyi's terms, 'ineffable' making it especially difficult to identify, challenge and transform or jettison: in short, the innovation literature cautions against some of the expectations attached to smart destinations. Notwithstanding these limitations, the literature on smart destinations, and smart systems generally, as well as design, is far stronger about Zahra and George's (2002) potential capacity than realised capacity. We have to turn to the innovation literature for deeper insights into the latter, as discussed in relation to entrepreneurship.

\section{ENTREPRENEURSHIP: INTEGRAL TO INNOVATION}

Probably the major question to be addressed is how the idea of smart destinations is to be implemented and, although many agents including the multi-scale state have a role in this, entrepreneurs necessarily are key as in any innovation (Braunerhjelm et al., 2010). The role of entrepreneurship in innovation is widely assumed, but rarely explicitly tested. However, in one of the rare systematic generic examinations of the influence of sector versus firm (with the latter implicitly including entrepreneurship), Clausen (2013, p. 527) finds evidence for both: 'agency, action and strategy at the firm level are important driving forces behind technological change .... [but] ..... industry effects are still important. ..... This lends empirical support to the literatures on technological regimes, sectoral patterns of technical change, and sectoral innovation systems'.

By extension, although the technological drivers behind the smart destination concept can be expected to exert substantial structural effects on innovation, there is considerable scope for agency at the firm 
level within destinations. This is exercised both through entrepreneurship and corporate entrepreneurship. Corporate entrepreneurship in major companies, including multinational enterprises (MNEs), plays a key role in developing smart tourism by instigating and implementing technological solutions requiring substantial investment. These firms can offer a variety of solutions, ranging from energyefficient and carbon-neutral solutions for destination logistics, building management, and public street lighting, to big data analytics tools and dashboards for optimization of public services. This is especially important because smart destinations may lack the required endogenous skills/knowledge to solve the innovation challenges required in the innovation process. This is particularly so in tourism which is largely technology reliant in the delivery of services and experiences (Hall \& Williams, 2020). In this respect, large or multinational companies can be knowledge gatekeepers for smart destination innovations, provided that this is consistent with their corporate objectives: where it is not, then the public sector or public-private partnerships usually have to fill the gap.

An important role is also played by entrepreneurs in small firms, and especially by start-ups, in the high-tech arena in tourism. The generic evidence emphasises the key role of start-ups in realising new product possibilities (Hoffman et al., 1998). Also, because new entrant firms are assumed to have higher productivity than exiting firms, they are a fundamental mechanism in increasing aggregate productivity levels in a sector or territory (Bloom \& Van Reenen, 2007).

Smart tourism commentators do not, of course, ignore the issues of leadership and co-ordination both of which are central to entrepreneurship and corporate entrepreneurship. For example, Buhalis and Amaranggana (2014) stress the importance of organisational agility, while Boes et al. (2015) specifically recognise that entrepreneurship and innovation sit at the core of the smart city concept. However, smart destination researchers have tended to draw more on the literature on design than on innovation. There are links between the two concepts, and specifically between the notions of entrepreneurship and design capability (Hobday, 2012, p. 28): 'Innovation studies should bring its knowledge of capabilities to the field of design to expand design beyond its usual treatment as process, activity, or output. In design studies, the capability dimension tends to be overlooked in discussions of wicked problems. However, the wicked problem at hand only ever exists in relation to the capabilities of the group attempting to solve the design problem'. And while researchers have acknowledged that smart cities are more entrepreneurial than others (Lombardi, 2012), there has been little analysis of the characteristics of entrepreneurial and corporate entrepreneurial activity within smart cities, let alone within smart destinations. 
The innovation capabilities, that Hobday urges designers to engage with, focus on the role of the entrepreneur, a figure that is integral to innovation. Two components are particularly important here. The first is linked to risks and especially to uncertainties, both of which are encountered during the innovation process (Schroeder et al., 1986). Risks which are known are ultimately a matter of transaction costs and can be dealt with in a variety of ways including seeking more knowledge, diversification, and insurance (Williams \& Baláž, 2015). In contrast the 'wicked problems' of uncertainty are far more challenging in framing decision making (Jalonen, 2012). Successful entrepreneurs are those who can operate under conditions of uncertainty, and this usually requires possession of dynamic capabilities (Teece et al., 2016), based on learning and previous experiences. Where learning is not sufficient, then they may have to 'muddle through' as the only way to advance the innovation process (Lindblom, 1959). The ability to accept and cope with muddling through in the face of uncertainty is an important characteristic of many entrepreneurs.

The second key component of entrepreneurship is the capacity to engage with challenges relating to markets, finance, and technology, and to garner and effectively utilise knowledge and other resources to address these. This is where entrepreneurs most clearly exercise agency. There are no studies of the role of tourism entrepreneurs in the innovation process in smart destinations, but Rodriguez et al. (2017) analyse the role of entrepreneurs and start-ups in the tourism innovation process. The entrepreneurs studied are found to be an important source of new knowledge and creativity especially because they mostly came from other fields (mainly tech-related) and they found tourism to be a fertile ground for new businesses/technological experimentation. However, these tech-entrepreneurs encounter risks and uncertainties because they lack sufficient knowledge about the specificities of tourism. Smart destinations are similarly likely to attract entrepreneurs with technological skills, but the need for tourism knowledge to apply these new technologies underlines that smart destination knowledge is highly situated. Smart tourism innovations, initially at least, have to be developed within the existing framework of previous smart and non-smart innovations, and the relationships and structures these have created over time. However, if a smart tourism innovation is a radical innovation, unleashing the forces of creative destruction, then it has to be built both on the ruins of the previous technological regime and - as discussed in the next section - its institutions.

Rodriguez et al. (2017) also emphasise the small scale and incremental character of the entrepreneurs' innovations and the associated difficulties of scaling up their businesses. This is also a critique of innovation projects in smart destinations generally (van Winden \& van den Buuse, 2017): a high 
percentage never proceed to a commercial scale or they remain as government subsidized experi-

ments. The innovation journey is often long and bumpy, with entrepreneurs encountering a number of inter-related and mutually reinforcing barriers, particularly in relation to finance: this is particularly important in smart destinations, because it is often very expensive to scale them up from prototypes to commercial products. Entrepreneurs require perseverance and commitment to cross the so-called 'valley of death', when the gap between expenditure and revenue may be cruelly exposed (Rodriguez et al., 2017): many succeed but many also fail in this respect.

In summary, the experimentation of the entrepreneurs plays a positive key role in lowering the levels of uncertainty about particular technologies as they create evidence (knowledge) about the likelihood of success or failure of applying particular types of technologies to tourism at the destination scale (see Figure 1). However, their experiences also demonstrate how challenging it is for entrepreneurs to engage with market uncertainties (see also Rodriguez et al., 2019). This is not only a question of evaluating and reframing the challenges by thinking about these 'wicked problems' but also of being able to marshal the necessary resources to address them, including reliance on their own resources, networking, and bootstrapping, especially in terms of securing finance, but also knowledge.

\section{SMART DESTINATIONS AS INNOVATION SYSTEMS}

Changing focus from the individual firm to the territorial scale, we find relatively more engagement with innovation concepts in the literatures on both the smart destination (Buhalis \& Amaranggana, 2014) and especially the smart city (Schafffers et al., 2011; Khomsi, 2016). According to Komninos (2002), for instance, the smart city requires the implementation of good practices in a given territory with the aim of stimulating innovation, learning, and knowledge transfer between stakeholders. In the same vein, Nam and Pardo (2011) consider that the smart city revolves around three dimensions - technological, human, and institutional - and they posit that innovation is particularly crucial for the institutional dimension. However, most of the smart literature then veers off to consider notions such as the creative city, knowledge (-based) city or learning city rather than engaging with the central territorial innovation concept, the innovation system. Where they do engage with the innovation system, it is often with the problematic concept of 'innovation ecosystem' (Zygiaris, 2013; Khomsi, 2016; Oh et al., 2016). In contrast, by reverting to the more foundational notion of innovation systems, we can draw on a more broadly-based focus on the role of knowledge and - via the concept of institutions - make a bridge to the lack of knowledge, that is to uncertainty (Feldman \& Massard, 2002). 
The innovation system concept, first introduced in the 1980s, rapidly became associated with the specific territorial articulation of the national system of innovation (Freeman, 1987; Lundvall, 1992). At the heart of this model is a theoretical focus on learning, knowledge, interactions and institutions: 'knowledge is a fundamental resource in the economy, that knowledge is produced and accumulated through an interactive and cumulative process of innovation that is embedded in a national institutional context, and that the context therefore matters' (Lindholm-Dahlstrand et al., 2018). It is only a relatively short leap from the notion of the national innovation system to that of the regional innovation system. Proponents of the latter (e.g. Cooke, 1992) argue that it is increasingly important given the relative decline in the powers of the national state, as well as being the more meaningful scale for interactions, networking and trust-building, reflecting the role of proximity and their greater informality of institutions (Cooke, 1997; Asheim \& Isaksen, 2002). Two aspects of the literature on regional innovations are particularly important to this paper.

First, the importance of institutions lies in the role of uncertainty (Edquist \& Johnson, 1997), as well as in managing conflicts and providing incentives. Fundamentally, institutions serve to reduce the need for knowledge about those you interact with: that is various formal (e.g. contract or patenting laws, or the legal system) and informal (practices and values) institutions mean that other agents can be engaged within broadly accepted rules of the game (Lundvall, 1992). Trust effectively reduces transaction costs and especially facilitates innovation which inherently involves engagement in negotiating uncertain future environmental changes, as well as uncertainty in the partners, suppliers etc.

The role of institutions is recognised as being a key to the development of smart destinations generally (Nam \& Pardo, 2011; Gretzel, 2015). However, there is considerable diversity in practice, and Meijer and Bolívar (2016) consider that smart city governance can assume a number of forms from institutional conservation to institutional transformation, with variable effectiveness. A number of researchers have responded to the need to develop new governance models, and modes of collaboration but the precedents for an effective 'institutional fix' are not strong in tourism (Hall \& Williams, 2020; Hjalager, 2010), where institutional weaknesses lead to reluctance to pool knowledge. These weaknesses will not evaporate in smart tourism destinations, because smart systems will mostly - at least initially - be embedded in existing institutions. 
The second lesson to be drawn from the regional innovation systems literature relates to the significant variance to be found in regional innovation systems. Neither the smart city, nor the smart destination, literature pay much heed to this issue. Instead, they tend to focus - often rather uncritically on more idealised and aspirational models. Nam and Pardo (2011), for example, are fairly typical in equating the smart city with the idealised learning city (Campbell, 2008), populated by smart people and characterised by creativity, social learning and education.

In contrast, innovation researchers have examined the differentiation of regional innovation systems, with Oinas and Malecki (2002) distinguishing between those which are genuine innovators, adopters and adapters. Cooke (2001) usefully differentiates between regions with strong and weak potential for regional innovation systems, distinguishing between what he terms infrastructural and superstructural issues. In terms of infrastructures, higher potential regions tend to have autonomous financial powers and regional private finance organizations, can influence policy on infrastructure and have a regional university-industry strategy. In contrast, regions with lower potential to develop regional innovation systems rely more on decentralised (national) spending and national financial organisations, have less influence on infrastructure, and have more piecemeal innovation projects. Furthermore, in territories with strong central governments and limited regional powers, this is likely to hinder development towards stronger regional innovation systems (Zabala-Iturriagagoitia et al., 2008).

How does this categorisation apply to smart destinations? The spatial definitions of smart destinations are problematic, but they are usually sub-regions within the larger scale of the regions that Cooke (2001) analyses (e.g. Bilbao rather than the Basque region). This means that they may benefit from selective favourable infrastructures in the larger regions. However, they characteristically have relatively weak autonomous finances, especially as so many are located in peripheral regions (Blomgren \& Sørensen, 1998). They also suffer from poor policy leverage both generally and specifically in relation to innovation (Hall \& Williams, 2020). They only rarely have regional universities (except in the case of urban/metropolitan tourism) and, even where these exist, the links between universities and firms tend to be weak. There is often a mismatch between the needs of the local business environments and university research which is likely to be especially pronounced in the case of (smart) tourism destinations. 
Turning to the superstructural level, regions with higher potential have a co-operative culture, interactive learning and an associative-consensus 'atmosphere'. This contrasts with lower potential regions which have a more competitive and individualistic culture, and institutional dissension and discord. While tourism is an enabling factor for innovation (Woodside et al., 2016) in regional innovation systems because of its contribution to quality of life and knowledge migration, the tourism sector itself is deeply characterised by weak collaboration, and limited consensus building (Bramwell \& Sharman, 1999). It is also characterised by fragmentation, and the challenges of tourism being a complex product distributed across a range of sectors (Hjalager, 2010; Hall \& Williams, 2020). As such, the concepts of sectoral and technological systems of innovation, commonly used in relation to distinct manufacturing sectors and distinct technology (product innovation), are less relevant for describing innovation systems in tourism destinations.

The innovation literature also cautions that an ideal innovation system cannot simply be transferred from drawing board to practice because 'innovation processes develop over time and involve the influence of many factors and feedback processes' (Edquist, 2006). The very importance attached to institutions means that there is sharp tension between the notion of embedded organic growth and the imposition from above of grand designs for a smart destination. For the same reason, we need to heed Hudson's (1999) arguments about the weight of structural determinants, and our limited understanding of how we 'unlearn': this will be as important as learning is to knowledge and innovation in smart destinations.

Despite these important reservations, innovation systems are necessarily dynamic, and there is no reason per se why a low potential regional innovation system cannot evolve (with appropriate state intervention) into a high potential one. The challenge for smart tourism destinations and for design lies in the scale of ambition, given the often laggardly performance of innovation in many if not most existing tourism destinations, which have trajectories more akin to the low rather than the high road to regional development (Hall \& Williams, 2020). Boschma (2005) provides useful insights into the challenges faced, differentiating between evolutionary versus revolutionary innovation policies. The evolutionary approach takes the internal context, including institutions, as the starting point. Although easier to achieve, it is constrained in scope to reproduction and strengthening, that is to incremental change. In contrast, the revolutionary approach seeks to restructure institutions, and, while more radical in scope, the outcome is surrounded in greater uncertainty. The development of smart destinations represents a range of challenges between the evolutionary and the revolutionary ideal types. However, at least for the foreseeable future, there is a need for revolutionary approaches in some instances 
because of the ambitions to realise sweeping and inter-connected technological, human and institutional innovations (Nam \& Pardo, 2011) - and this constitutes a very formidable challenge. It is also worth underlining (again) that different types of regions face different types of barriers (e.g. institutional thinness, lack of regional cooperation or mutual trust, industrial structures based on outdated technologies, etc.) to develop their innovation systems or to develop as smart destinations. Thus, there are no one-size-fits-all policies and success stories that could be copied as such to other regions (Isaksen, 2001) or destinations.

While the literatures on the smart city and smart destination (and design) sets out an ambitious agenda, there is no clear road map of how this can be realised. However, the innovation systems literature does provide the outlines of such a route. Benneworth (2007), for example, outlines the five key stages in the regional innovation journey that transforms an 'ordinary' region into a highly innovative one, such as is implied by the notion of smart destinations. These are: gathering a cadre of enthusiasts, arriving at an agreed vision and strategy, piloting novel activities, mainstreaming and renewal. However, transition between stages is challenging, and may not always be achieved, as a number of critical points have to be surpassed on the journey. Benneworth (2007, p. 7) concludes that: 'It can be hard for regional authorities to distinguish between competing claims from different actors about which activities public policy should support. ... Balancing investment in existing excellence with attractive potential is difficult'. In other words, we come round full circle to the core issue of uncertainty as both the driver and the greatest challenge faced by the smart destination agenda. This also reminds us of a point made earlier, that smart cities do not offer a win-win strategy for tourism as a whole, because an innovation system is not a 'merry-go-round of equals'.

\section{CONCLUSIONS}

Smart tourism, and its specific manifestation as smart destinations, has become the 'new kid on the block' in tourism policy and research circles (Gretzel et al., 2015, p. 180). An imprecise understanding of smart tourism as a development tool (both in conceptual and practical terms) can lead to ambiguity in its use in tourism strategies for destinations. Therefore, the concept carries a risk of becoming a policy buzzword (cf. Makkonen \& Inkinen, 2014). Moreover, the ensuing literature has often lacked critical content. In part, this is because while smart destination discourses have included discussion of design and design thinking (see Fesenmaier \& Xiang, 2017), their engagement with the 
innovation literature has been far sparser, despite innovation being a central foundation to smart tour-

ism. This paper has drawn on four aspects of the innovation literature that provide insights into smart destinations.

Firstly, smart destinations, in common with other innovations, can be understood as driven by uncertainty (Knight, 1921): they push the boundaries of the unknown (Dvir \& Pasher, 2004, p. 20) as firms innovate to respond to, and seek to reduce, uncertainty. One of the important lessons offered by the innovation literature is that innovations also generate uncertainties for the entities involved as well as for their competitors: smart destinations represent the opening of a new campaign in Baumol's (2002) 'innovation arms race'. Innovations can fail, and cause the failure of the associated firms, but the realignment of competitiveness will also have negative consequences for their competitors. This is especially so with respect to when smart destinations involve radical innovations which represent 'creative destruction' (Schumpeter, 1942). Such innovations do not represent universal competitiveness strategies available to all, or zero-sum games: there are winners and losers.

Secondly, the smart tourism literature has been heavily influenced by the notion of living in a 'datadriven sensor society' (Fesenmaier \& Xiang 2017, p. 10), and this has made some of the literature 'techno-myopic' (Gretzel et al., 2015). The innovation literature puts far more emphasis on knowledge, and specifically on knowledge transfer issues, including the differentiation between tacit and codified knowledge (Polanyi, 1958). While much of the emphasis of the smart destination literature is on codifying various forms of tacit knowledge as is also the case with the innovation literature, the latter offers the framework of absorptive capacity for its analysis (Zahra \& George, 2002). This is especially relevant as smartness can be interpreted as the outcome of enhancing absorptive capacity. However, the innovation literature cautions against under-estimating the ineffable nature of much tacit knowledge, and the challenges in transitioning from potential to realized capacity, that is in creating and implementing innovations.

Thirdly, the innovation literature takes us to the role of entrepreneurs in the implementation of the smart tourism agenda. Both large and small firms have roles to play, with only the former (or the state) having the resources necessary to deliver some of the major infrastructural innovations that are required. However, small firms also play a key role, and in this respect the entrepreneur is more than a mechanism in the innovation process, as he or she exercises agency: unhelpfully, Schumpeter was inconsistent on this point (see Hall \& Williams, 2020). The limited evidence on entrepreneurs in technology-driven tourism firms suggests that they have backgrounds in the technology sector which reduces technological uncertainty, but means that their lack of tourism knowledge generates other 
uncertainties. This draws attention to the fact that successful entrepreneurs are required to operate under conditions of uncertainty, and this requires agility (Teece et al., 2016; Williams et al., 2020) as well as perseverance and commitment (Rodriguez et al., 2017). These capacities are likely to be unevenly developed in the cohort of entrepreneurs - new and old to a destination - who seek to drive the smart agenda, meaning that there will be high rates of firm failure. Indeed, relatively high exit rates (as well as entrance rates) of firms are integral to raising competitiveness (Bloom \& Van Reenen, 2007), which is part of the smart tourism agenda. This leads to the conclusion that smart destinations have to be built on the ruins of the previous technological regime, and the failure of existing entrepreneurs as well as the spectacular success stories of other entrepreneurs.

Fourthly, the regional innovation system concept provides useful insights into smart destinations as innovation systems. Two main points are important. That there is a need for institutional innovation to accompany technological shifts (Nam \& Pardo, 2011), but the precedents for an effective 'institutional fix' are unfavourable in tourism (Hjalager, 2010). And, following Cooke (2001), it is important to recognize that regions (and therefore destinations) vary markedly in terms of their potential to become effective innovation systems. And, neither grand designs nor evolutionary changes automatically produce smart destinations, rather - as with innovation systems (Benneworth, 2007) - there is often a tortuous journey to be followed, which not all regions complete, in part because of their inadequate innovation capacities.

Looking towards a future research agenda, there are several areas which merit further exploration by those researching the design of smart destinations, and smart tourism more generally. First, and most obviously this paper only looked at the supply side, and there is need for further research on how tourists generally respond to the opportunities and uncertainties associated with smart innovations: there is considerable evidence of end user resistance to tourism innovations because of lack of perceived usefulness or their perception of risks (Rodriguez et al., 2019). Similarly, Tussyadiah and Wang (2016) comment on how perceived lack of control leads tourists to be reluctant to utilize smartphone-related innovations because of a fear they will lose control over their tourism experiences: this is a fundamental challenge to the smart destination concept, and to design, and one which is particularly acute for product rather than process innovation.

Secondly, there is a need to research the roles and interests of different agents in the implementation of smart destinations. What is the role of small firms as opposed to large firms and how do they inter- 
relate? Moreover, who are the private sector agents who actually drive these agendas - are they high-

tech companies and high-tech entrepreneurs who come from outside the sector, with attendant tourism knowledge deficits, or are they existing firms within the sectors who are adopting and adapting or - perhaps - even creating new technologies? In other words, to what extent is the embedded knowledge in existing destinations an opportunity or a barrier to smart destination innovation? The role of the state as an innovation leader is also important, but many public sector organizations have experienced considerable uncertainty when seeking to contribute to integrating new technologies, relating to big data, to the fast moving and still relatively new concept of the smart city (Okwechime et al., 2018). Moreover, in the wake of neo-liberalism, urban governments in most countries have significantly weakened capacity to invest in the infrastructural, human capital and formal institutional innovations that are required (Nam \& Pardo, 2011) to support the private sector or to act in an entrepreneurial capacity. Does the urban state need to make a come-back if the smart destination agenda is to be realized? Another important issue is the extent to which different types of tourism destinations provide different challenges in terms of their constitution as regional innovation systems: to what extent do highly urban destinations differ from semi-rural, or spatially dispersed destinations?

Thirdly on the supply side, there is need to investigate the innovation process or processes that are central to the realization of the smart destination agenda. For example, there is still relatively little known about how information, let alone the more complex concept of knowledge, is effectively transformed into innovation. In other words, to what extent do firms in a tourism destination either individually or collectively follow through the four stages of Zahra and George's model of absorptive capacity, that is from identification of knowledge to exploitation of knowledge? The evidence to date is mainly about the potential efficacy of identification and assimilation of knowledge, and yet there is a growing strand of literature which contends that effective development requires an ambidextrous approach which encompasses both exploration and exploitation (Ferraris et al., 2019). These different stages of the absorptive capacity require different competences, if the firm is to reap the benefit of its ideation and or research and development, while also maintain long run competitiveness. Analysis of these issues requires longitudinal studies that examine both the innovation successes and failures of individual firms, the risks and uncertainties encountered and how these were overcome, as the smart destination agenda is increasingly rolled out.

This leads to a fourth issue which is the need for smart destinations to address both successful and failed innovations. Innovation is not simply the process of implementing some predetermined product via a predetermined pathway. Rather it involves a process of learning and knowledge accumulation both about the product and the innovation process (Rodriguez, et al., 2017). The challenge for smart 
destinations is to manage 'failure' so that this accumulated knowledge is not lost, but is shared, and reused in various ways, either in product design or the innovation journey of these same or of other entrepreneurs.

While design and technology can play a role in all these issues, innovation adds a more comprehensive perspective within which to understand and inform the continued development or management of smart destinations. More broadly, we contend that as all forms of change (incremental or radical) represent innovations, the focus should be on smart destinations as 'innovative destinations'.

\section{REFERENCES}

Asheim, B., \& Coenen, L. (2006). Contextualising regional innovation systems in a globalising learning economy. Journal of Technology Transfer, 31, 163-73.

Asheim, B., \& Isaksen, A. (2002). Regional innovation systems. Journal of Technology Transfer, 27(1), 77-86.

Atzori, L., Iera, A., \& Morabito, G. (2010). The internet of things: a survey. Computer Networks, 54(15), 2787-2805.

Autio, E., Sapienza, H., \& Almeida, J. (2000). Effects of age at entry, knowledge intensity, and imitability on international growth. Academy of Management Journal, 43(5), 909-24.

Baumol, W. (2002). The free market innovation machine. Princeton: Princeton University Press.

Benckendorff, P., Sheldon, P., \& Fesenmaier, D. (2014). Tourism information technology. Oxford, UK: CAB International.

Benneworth, P. (2007). Leading innovation. London: NESTA Research Report.

Blackler, F. (2002). Knowledge, knowledge work and organizations. In Choo, C.W. and Bontis, N. (eds), The Strategic Management of Intellectual Capital and Organizational Knowledge (pp. 47-62). New York: Oxford University Press.

Blomgren, K. B., \& Sørensen, A. (1998). Peripherality-factor or feature? Progress in Tourism and Hospitality Research, 4(4), 319-336.

Bloom, N., \& Van Reenen, J. (2007). Measuring and explaining management practices across firms and countries. The Quarterly journal of Economics, 122(4), 1351-1408.

Boes, K., Buhalis, D., \& Inversini, A. (2015). Conceptualizing smart tourism destination dimensions. In I. Tussyadiah, A. Inversini (eds.), Information and Communication Technologies in Tourism (pp. 391-403). Dordrecht: Springer. 
Boes, K., Buhalis, D., \& Inversini, A. (2016). Smart tourism destinations: ecosystems for tourism destination competitiveness. International Journal of Tourism Cities, 2(2) 108-124.

Boschma, R.A. (2005). Rethinking regional innovation policy. In Fuchs, G. and Shapira, P. (eds.) Rethinking Regional Innovation and Change (pp. 249-271). Dordrecht: Springer,.

Bramwell, B., \& Sharman, A. (1999). Collaboration in local tourism policymaking. Annals of tourism research, 26(2), 392-415.

Buhalis, D., \& Amaranggana, A. (2014). Smart tourism destinations. In Z. Xiang \& I. Tussyadiah (Eds.), Information and Communication Technologies in Tourism 2014 (pp. 553-564). Heidelberg: Springer.

Campbell, T. (2009). Learning cities: Knowledge, capacity and competitiveness. Habitat International, 33(2), 195-201.

Chell, E. (2001). Entrepreneurship: Globalization, Innovation and Development. London: Thomson Learning.

Cohen, W. M. \& Levinthal, D.A. (1990). Absorptive capacity: A new perspective on learning and innovation. Administrative Science Quarterly, 35(1), 128-52.

Cooke, P. (2001). Regional innovation systems, clusters and the knowledge economy. Industrial and Corporate Change, 10(4), 945-974.

Cooke, P., Uranga, M. G., \& Etxebarria, G. (1997). Regional innovation systems: Institutional and organisational dimensions. Research policy, 26(4-5), 475-491.

Cross, N. (1990). The nature and nurture of design ability. Design Studies, 11(3), 127-140.

Crossan, M., \& Apaydin, M. (2010). A multi-dimensional framework of organizational innovation. Journal of Management Studies, 47(6), 1154-1191.

Dvir, R., \& Pasher, E. (2004). Innovation engines for knowledge cities. Journal of Knowledge Management, 8(5), 16-27.

Edquist, C. (2006). Industrial Policy from a Systems Innovation Perspective, CIRCLE, Centre for Innovation, Research and Competence in the Learning Economy.

Edquist, C., \& Johnson, B. (1997). Institutions and organizations in systems of innovation. In: Edquist, C. (Ed.), Systems of Innovation (pp. 41-63). Frances Pinter, London.

Feldman, M., \& Massard, N. (eds.) (2002). Institutions and Systems in the Geography of Innovation. Boston: Kluwer Academic Publishers. 
Ferraris, A., Erhardt, N., \& Bresciani, S. (2019). Ambidextrous work in smart city project alliances.

The International Journal of Human Resource Management, 30(4), 680-701.

Fesenmaier, D., \& Xiang, Z. (2016). Introduction to tourism design and design science in tourism. In Fesenmaier, D. R., \& Xiang, Z. (Eds.) (2016). Design science in tourism: Foundations of destination management (pp. 3-16). Cham: Springer.

Freeman, C. (1987). Technology Policy and Economic Performance. London: Pinter Publishers.

Glasmeier, A., \& Nebiolo, M. (2016). Thinking about smart cities. Sustainability, 8(11), 1-11.

Gretzel, U., Sigala, M., Xiang, Z., Koo, C. (2015). Smart tourism: Foundations and developments. Electron Markets, 25, 179-188.

Gretzel, U, Zhong, L., \& Koo, C. (2016). Application of smart tourism to cities. International Journal of Tourism Cities, 2(2) 1-10.

Grant, K. A. (2007). Tacit knowledge revisited-we can still learn from Polanyi. The Electronic Journal of Knowledge Management, 5(2), 173-180.

Hall, C. M., \& Williams, A. M. (2020). Tourism and Innovation second edition, London: Routledge Hatchuel, A. (2002). Towards Design Theory and Expandable Rationality. Journal of Management and Governance, 5(3-4), 260-73.

Hernández, R. J., Cooper, R., Tether, B., \& Murphy, E. (2018). Design, the language of innovation. She Ji: The Journal of Design, Economics, and Innovation, 4(3), 249-274.

Hjalager, A. M. (2010). A review of innovation research in tourism. Tourism Management, 31(1), 112.

Hjalager, A. M. (2014). Disruptive and sustaining innovation: The case of rural tourism. In G. A. Alsos, D. Eide, \& E. L. Madsen (Eds.) Handbook of Research on Innovation in Tourism Industries (pp. 56-83), Cheltenham: Edward Elgar Publishing.

Hobday, M., Boddington, A., \& Grantham, A. (2011). An innovation perspective on design: Part 1. Design Issues, 27(4), 5-15.

Hobday, M., Boddington, A., \& Grantham, A. (2012). An innovation perspective on design: Part 2. Design issues, 28(1), 18-29.

Hoffman, K., Parejo, M., Bessant, J., \& Perren, L. (1998). Small firms, R\&D, technology and innovation in the UK. Technovation, 18(1), 39-55.

Isaksen, A. (2001). Building regional innovation systems. Canadian journal of regional science, 24(1), 101-120. 
Ivars-Baidal, J. A., Celdrán-Bernabeu, M. A., Mazón, J. N., \& Perles-Ivars, A. F. (2019). Smart des-

tinations and the evolution of ICTs: a new scenario for destination management? Current Issues in Tourism, 22(13), 1581-1600.

Jalonen, H. (2012). The uncertainty of innovation. Journal of Management Research, 4(1), 1-53.

Johansson-Sköldberg, U., Woodilla, J., Çetinkaya, M. (2013) Design Thinking: Past, Present and Possible Futures. Creativity and Innovation Management, 22(2) 121-146.

Khomsi, M. R. (2016). The smart city ecosystem as an innovation model. Technology Innovation Management Review, 6(11), 26-31.

Knight, F. H. (1921). Risk, uncertainty and profit. New York: Hart, Schaffner and Marx.

Lamsfus, C. \& Alzua-Sorzabal, A. (2013). Theoretical framework for a tourism internet of things: smart destinations. Journal of Tourism and Human Mobility, 2, 15-21.

Lindblom, C. E. (1959). The science of "muddling through". Public administration review, 19(2), 7988.

Lindholm-Dahlstrand, Å., Andersson, M., \& Carlsson, B. (2018). Entrepreneurial experimentation. Small Business Economics, 53, 591-610.

Lundvall, B.-Å. (Ed.). (1992). National systems of innovation. London: Pinter.

Makkonen, T., \& Inkinen, T. (2014). Spatial scaling of regional strategic programmes in Finland. Norsk Geografisk Tijdsskrift, 68(4), 216-227.

Malanga, S. (2004). The curse of the creative class. City, 14(1), 1-15.

Marxt, C. \& Hacklin, F (2005). Design, product development, innovation. Journal of Engineering Design, 16(4), 413-421

Maskell, P., \& Malmberg, A. (1999). Localised learning and industrial competitiveness. Cambridge Journal of Economics, 23(2),167-85.

Meijer, A., \& Bolívar, M. P. R. (2015). Governing the smart city. International Review of Administrative Sciences, 82(2), 392-408

Nam, T., \& Pardo, T. (2011). Conceptualizing Smart City with Dimensions of the Technology, People, and Institutions. In Proceedings, 12th Annual International Conference on Digital Government Research: 282-291.

O’Connor, G. (2008). Major Innovation as a Dynamic Capability. Journal of product innovation management, 25(4), 313-330. 
Oh, D. S., Phillips, F., Park, S., \& Lee, E. (2016). Innovation ecosystems: A critical examination. Technovation, 54, 1-6.

Oinas, P. \& Malecki, E.J. (2002). The evolution of technologies in time and spaces. International Regional Science Review, 25(1), 102-131.

Okwechime, E., Duncan, P. \& Edgar, D. (2018). Big data and smart cities. Informational Systems and e-Business Management, 16(3), 601-625.

Oughton, C., Landabaso, M. \& Morgan, K. (2002). The regional innovation paradox. The Journal of Technolopgy Transfer, 27(1), 97-110.

Ozseker, D. B. (2019). Towards a model of destination innovation process: an integrative review, The Service Industries Journal, 39(3-4), 206-228.

Polanyi, M. (1958). Personal Knowledge, London: Routledge and Kegan Paul.

Polanyi, M. (1966). The Tacit Dimension. London: Routledge \& Kegan Paul.

Rodriguez, I., Williams, A.M., \& Brotons, M. (2017). The innovation journey of new-to tourism entrepreneurs. Current Issues in Tourism, 22(8), 877-904.

Rodríguez, I., Williams, A. M., \& García, H. (2019). Customer resistance to tourism innovations. Journal of Travel Research, doi.org/10.1177/0047287519843188

Schroeder, R., Van de Ven, A., Scudder, G., \& Polley, D. (1986). Managing innovation and change processes. Agribusiness, 2(4), 501-23.

Schumpeter, J. A. (1942). Socialism, capitalism and democracy. Harper and Brothers.

Szerb, L. \& Terjesen, S. (2010) Measuring the competitiveness of small businesses. Available at: http://www.kmu.unisg.ch.

Teece, D., Peteraf, M., \& Leih, S. (2016). Dynamic capabilities and organizational agility. California Management Review, 58(4), 13-35.

Thomas, R., \& Wood, E. (2015). The absorptive capacity of tourism organisations. Annals of Tourism Research, 54, 84-99.

Thomas, R., \& Wood, E. (2014). Innovation in tourism: Re-conceptualising and measuring the absorptive capacity of the hotel sector. Tourism Management, 45, 39-48.

Trunfio, M., \& Campana, S. (2019). Drivers and emerging innovations in knowledge-based destinations: Towards a research agenda. Journal of Destination Marketing \& Management, 14, 100370. 
Tussyadiah, I., \& Wang, D. (2016). Tourists' attitudes toward proactive smartphone systems.

Journal of Travel Research, 55(4), 493-508.

van Winden W., \& van den Buuse, D. (2017). Smart City Pilot Projects: exploring the dimensions and conditions of scaling Up. Journal of Urban Technology, 24(4), 51-72.

Williams, A. M., \& Baláž, V. (2009). Low-cost carriers, economies of flows and regional externalities. Regional Studies, 43(5), 677-691.

Williams, A. M., \& Baláž, V. (2015). Tourism, risk and uncertainty: theoretical reflections. Journal of Travel Research, 54(3), 271-287.

Williams, A. M., Rodriguez, I., \& Skokic, V. (2020) Innovation, risk and uncertainty: a study of tourism entrepreneurs. Journal of Travel Research, doi.org/10.1177/0047287519896012.

Woodside, A.G., Bernal, P.M., \& Coduras, A. (2016). The general theory of culture, entrepreneurship, innovation, and quality-of-life. Industrial Marketing Management, 53, 136-159.

Zahra, S.A., \& George, G. (2002). Absorptive capacity. Academy of Management Review, 27(2), 185-203.

Zabala-Iturriagagoitia, J. M., Gutiérrez-Gracia, A., \& Jiménez-Sáez, F. (2008). Benchmarking innovation in the Valencian community. European Urban and Regional Studies, 15(4), 333-347.

Zygiaris, S. (2013). Smart city reference model. Journal of the Knowledge Economy, 4(2), 217-231. 
1. What is the contribution to knowledge, theory, policy or practice offered by the paper?

This research advances the understanding of the concepts and theory related to smart tourism. The contribution of this paper lies in its approach to study smart destinations through the concepts and ideas discussed in the innovation literature rather than from the perspective of the 'smart' literature which has held an (overly) optimistic view on the contribution of information on smart destinations. Approaching smart tourism from the standpoint of innovation literature, rather than design, provides a broader perspective, which allows critical insight into the importance of knowledge (rather than "mere" information) in the development and management of smart destinations. This opens up critical questions concerning the contribution of uncertainty, entrepreneurship and innovation systems (all of which are themes that are largely missing from the discussions of smart destinations. As such, innovation adds a more comprehensive and holistic perspective within which to understand and inform the continued development and management of smart destinations.

\section{How does the paper offer a social science perspective / approach?}

Smart tourism is a social phenomenon that has been extensively researched from an information, technology and design perspectives but limited attention has been given to the notion of smart tourism from the perspective of the innovation theory. This conceptual piece of work aims to overcome this gap broadening the conceptualization of smart tourism by bringing key interrelated topics from the broader field of social science, mainly economics, economic sociology and management, and particularly from the literature of innovation studies. In the process of theoretical discussion, the paper tries to understand the complex and overlapping relationship of innovation and design in the context of smart tourism. Understanding what smart really means, that is embedding it in a broader theoretical framework, is important to provide a foundation for designing and developing truly smart destinations. 


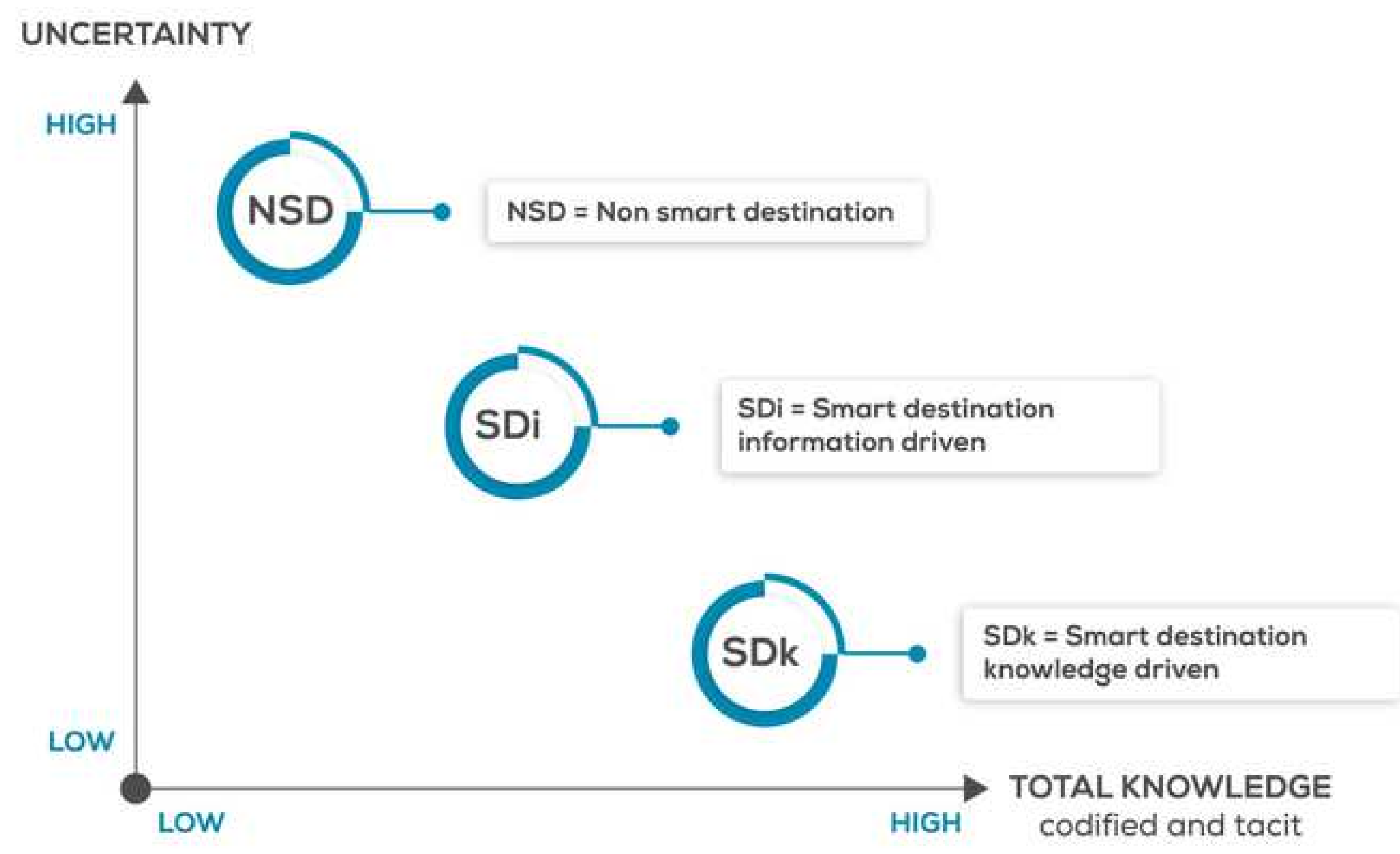

SDi = Smart destination

information driven

SDk = Smart destination knowledge driven codified and tacit 